\title{
Evaluating Quality Control Decisions: A Simulation Approach
}

\author{
Mohamed K. Omar ${ }^{1}$ and Sharmeeni Murugan ${ }^{2}$ \\ ${ }^{1}$ Nottingham University Business school Malaysia \\ ${ }^{2}$ Faculty of Engineering $\mathcal{E}$ Technology Multimedia University \\ Malaysia
}

\section{Introduction}

Quality has become one of the core factors for almost all manufacturing and service companies that aim to achieve customer satisfaction. Therefore, improving quality is considered to be one of the efforts that companies consider a must to attain customer loyalty in today's complex global competitive environment. Studies concluded that any serious endeavour to improve quality will lead to an increase of cost of the product or service. Obviously, improving quality has its own costs. As a result, measuring cost of quality is very important as it provides valuable insights into the different cost of quality components. Thus, favourable returns on investment maybe achieved. For this fact, the quality cost concept was introduced and implemented in many manufacturing and service companies. The first model of cost of quality was introduced by Feigenbaum (1956) known as the P-A-F model which consists of prevention, appraisal and failure cost. Feigenbaum (1991) categorized the model into two major areas: costs of control (costs of conformance), and costs of failure of controls (costs of non-conformance), which since then used by numerous research studies (for example, Sumanth and Arora (1992), Burgess (1996), Purgslove and Dale (1995), Gupta and Campbell (1995), Chang et al. (1996), Sorqvist (1997)).

Most of the reported literature does not provide a single universal definition for cost of quality (Dale and Plunkett (1999)). However, cost of quality is usually best understood in terms of the sum of costs of conformance and the costs of non-conformance which was first introduced by Crosby (1979). Here, cost of conformance is known as the costs associate with quality requirement for achieving specific quality standards for a product or service. On the other hand, cost of non-conformance is known as the cost of failure to deliver the required standard of quality for a product or service. From the voluminous literature, one may categorized the cost of quality models into five generic models which are: P-A-F model, Crosby model, opportunity or intangible cost model, process cost models and ABC (activity based costing) model. Traditional cost accounting approaches typically used to measure cost of quality has been reported in the literature to have serious limitations when dealing with the components of intangible costs (see Son (1991), Chiadamrong (2003) and Sharma (2007)). As manufactures continue to improve their factories, they discover that existing cost measure systems should be updated and no matter how sophisticated and reliable these economic evaluation measure maybe, such problems still remain if unreliable cost information is not obtained as inputs for these economic evaluation, Chiadamrong (2003). 
It is true to state that cost of quality modelling will provides more accurate approach to determine the cost involved in any quality control activities. However, the challenge does not end here. The cost of quality model must be used to determine the cost of improving activities associated with quality control strategies introduced to improve customer expectations. Therefore, a realistic cost of quality estimation could be determined that allows managers to show the economic benefit or otherwise of that specific quality control strategy. In other words, a quality control improvement strategy can only be justified if the increase in profitability is sufficient to cover the costs involved in the implementation. Once the cost of quality model is developed, a simulation can be used to determine the impact of any quality control strategy that a company wish to investigate. Among the strategies that manufacturing companies may consider investigating would be the allowable defect rate in some process or operations. In this case, simulation could be used to calculate the impact of defective rate of that operation on the overall profitability and productivity of the manufacturing system. Moreover, simulation could be used to study the system before and after some quality control improvement policy. Once the study is completed, a true picture about the cost of that policy could be determined as well as the impact of that policy on the overall defect rate.

This chapter is organized in the following manner; the literature review is presented in section 2 and followed by cost of quality model in section 3. Problem and solution methodology are presented in section 4 . Experiment design and model verification, results and discussions are presented in sections 5 and 7 respectively. Finally, conclusions are presented in section 7 .

\section{Literature review}

In its simplest definition of cost of quality, the American Society for Quality Control (ASQC (1971)) and the BS6143 Part 2 (1990) define cost of quality as the costs incurred in ensuring quality, together with the loss incurred when quality is not achieved. Feigenbaum (1956, 1961) introduces the so called PAF model in which cost of quality was classified into four components, prevention, appraisal and failure (internal and external) costs. In Plunkett and Dale (1987) survey, it is stated that literature suggests that most of the researchers use the PAF model for measuring cost of quality. However, Schiffauerova and Thomson (2006) reported that PAF model concept is not the only one since other models were found in the literature to be developed, discussed and used as detailed in Table 1. It is worth noting that Table 1 was originally developed by Schiffauerova and Thomson (2006) and updated by the authors.

The importance of cost of quality has been reported in many research works, Moyer and Gilmore (1979) reported that cost of quality could reach as high as 38\% of sales and Albright and Roth (1992) estimated that the cost of quality may represents 30\% of all manufacturing costs in the United States. Moreover, Harry and Schroeder (2000) asserted that most companies would find that cost of quality, if properly evaluated, falls somewhere between 15 and $25 \%$ of total sale-rather that 3-7\% that often assumed. In other study, Giakatis et al. (2001) report that cost of quality represents considerable portion of company's total costs. More recently, Kent (2005) estimated that the turnover rates faced by companies are between 5 to $15 \%$ of the overall cost of quality. The benefits of implementing cost of quality system in any profitable organization has been reported extensively in the cost of quality literature, for example, Prickett and Rapley (2001) highlighted four common benefits that any organization is bound to gain from implementing cost of quality system :(1) it will be 


\begin{tabular}{|c|c|c|}
\hline Generic model & Cost/ activity categories & $\begin{array}{l}\text { Examples of publications } \\
\text { describing, analyzing or } \\
\text { developing the model }\end{array}$ \\
\hline P-A-F models & $\begin{array}{l}\text { Prevention + appraisal }+ \\
\text { failure }\end{array}$ & $\begin{array}{l}\text { Feigenbaum (1956), } \\
\text { Purgslove and Dale (1995), } \\
\text { Merino (1988), Chang et } \\
\text { al.(1996), Sorqvist (1997), } \\
\text { Plunkett and Dale } \\
\text { (1988),Tatikonda and } \\
\text { Tatikonda (1996), Bottorff } \\
\text { (1997), Gupta and Campbell } \\
\text { (1995), Burgess (1996), } \\
\text { Dawes (1989), Sumanth and } \\
\text { Arora (1992), Morse (1983), } \\
\text { Weheba and Elshennawy } \\
\text { (2004), etc. }\end{array}$ \\
\hline Crosby's model & $\begin{array}{l}\text { Conformance + non- } \\
\text { conformance }\end{array}$ & $\begin{array}{l}\text { Suminsky (1994) and Denton } \\
\text { and Kowalski (1988) }\end{array}$ \\
\hline $\begin{array}{l}\text { Opportunity or intangible } \\
\text { cost models }\end{array}$ & $\begin{array}{l}\text { Prevention }+ \text { appraisal }+ \\
\text { failure }+ \text { opportunity } \\
\text { Conformance }+ \text { non- } \\
\text { conformance }+ \text { opportunity } \\
\text { Tangibles }+ \text { intangibles } \\
\text { P-A-F (failure cost includes } \\
\text { opportunity cost) }\end{array}$ & $\begin{array}{l}\text { Sandoval-Chavez and } \\
\text { Beruvides (1998) and } \\
\text { Modarres and Ansari (1987) } \\
\text { Carr (1992) and Malchi and } \\
\text { McGurk (2001) } \\
\text { Juran et al.(1975) } \\
\text { Heagy (1991) and } \\
\text { Chiadamrong (2003) }\end{array}$ \\
\hline Process cost models & $\begin{array}{l}\text { Conformance + non- } \\
\text { conformance }\end{array}$ & $\begin{array}{l}\text { Ross (1977), Marsh (1989), } \\
\text { Goulden and Rawlins (1995), } \\
\text { Crossfield and Dale (1990) }\end{array}$ \\
\hline ABC models & $\begin{array}{l}\text { Value added + non-value } \\
\text { added }\end{array}$ & $\begin{array}{l}\text { Cooper (1988), Cooper and } \\
\text { Kaplan (1988), Tsai (1998), } \\
\text { Jorgenson and Enkerlin } \\
\text { (1992), Dawes and Siff (1993) } \\
\text { and Hester (1993) }\end{array}$ \\
\hline
\end{tabular}

Table 1. Generic cost models and cost categories adopted from Andrea and Thomson (2006). 
able to focus upon areas of poor performance that need improvements, (2) it will have the opportunity to monitor the progress of ongoing improvement activities, (3) it will have an opportunity to plan for quality improvement and (4) it will be able to communicate better within the organization for improving the overall of the quality control.

Moreover, Schiffauerova and Thomson (2006) in their extensive literature review on cost of quality indicate that companies that use cost of quality programs have been quite successful in reducing cost of quality and improving the quality for the customer.

Although the impact of implementing cost of quality systems on increasing profit of any organization is obvious, Yang (2008) reported that the literature on cost of quality systems implementation indicates that most of companies do not know the true cost of their own quality. Despite that $82 \%$ of companies in the United Sates are involved in quality programs, only 33\% actually compute the cost of quality (Harry and Schroeder, 2000), and in north-east England $66 \%$ of organization do not make use of quality costing as reported by Prickett and Rapley (2001). Some studies have highlighted reasons for the lack of implementing cost of quality systems in practice, Harry and Schroeder (2000) state that many significant quality related costs cannot be captured by most types of accounting systems. Chen and Yang (2002) related the difficulties to measure cost of quality to the fact that there is a lack of adequate methods for determining the financial consequences of poor quality. Moreover, Chiadamrong (2003) has concluded that there is a widespread belief that quality cost cannot be measured in practical terms because traditional cost accounting systems have not been adapted to quantify the value of quality. The need for quantifying cost of quality as stated by Yang (2008) and has been reported in the literature by many researchers, (Feigenbaum (1956); Juran (1952, 1989); Krishnan et al. (2000); Giakatis et al. (2001); Prickett and Rapley (2001), Chen and Yang (2002). However, there are evidences in the literature that clearly indicate that quantifying cost of quality has been neglected by most of organization (Harry and Schroeder (2000) and Omachonu et al. (2004)).

Quality performance is not something that can be readily altered in practice therefore one cannot test with the actual system. Most of the operations system are interconnected and subjected to both variability and complexity. Hence it is impossible to predict the performance of operation systems that are potentially subjected to variability, interconnectedness and complexity. Simulation has been used to overcome this problem and to investigate on the effect of quality loss financially and also examines the effect of different quality strategies on the financial aspect. Simulation provides a flexible technique to model an extensive array of issues that arise relating to quality and manufacturing. The flexibility of simulation methods permitted the invention of models with greater complexity than analytical techniques. Burgess (1996) constructed a simulation model based on system dynamics nature where the model was incorporated with the traditional P-A-F element. The model has facilitated the precise examination of the major relationships concerning conformance quality and costs at the organizational level. Gardner et al. (1995) examines the quality improvement in a manufacturing system by using simulation approach. The modelling was more complicated as it allows the defective parts to move along the assembly operations to examine the impact on the profitability and productivity.

Tannock $(1995,1997)$ emphasizes the significance of process capability in the selection of quality control strategy and revealed the economic advantages of control charting where special or assignable causes exist. Clark and Tannock (1999) investigate the use of simulation model to estimate the quality cost associated with multi manufacturing system setup and quality control strategies. This approach was validated and aligned with actual costs at a 
case study company. Although there are voluminous literatures written on cost of quality, very few literatures were written on tracing the invisible element of cost of quality and also the method in measuring the element of cost of quality.

The literature review presented so far indicates that estimating cost of quality is not a simple and straight forward issue. Moreover, the literature shows that there are several methods that can be used to determine cost of quality. Moreover, simulation stands as a favourite approach that might be used to investigate quality improvements justification in terms of profitability for a specific cost of implantation. Obviously, cost of quality model must first be developed and then simulation is followed to investigate the impact of some quality strategies and or improvements.

\section{The cost of quality model}

In this section of the chapter we, intend to provide a brief description of the model developed by Son and Lie (1991) and the way it was modified to be suitable for our research idea. First, the notations of the model are presented.

Notations

$\begin{array}{ll}t & \text { sampling interval } \\ n & \text { sample size per sampling } \\ \Theta & \text { average number of assignable cause per hour } \\ d_{1} & \text { mean time spent to identify an assignable cause } \\ d_{2} & \text { mean time spent to correct an assignable cause } \\ g & \text { time required to sample a product } \\ t_{0} & \text { time inspection of the acceptance sampling } \\ c_{a} & \text { cost of investigating acceptance sampling } \\ \Gamma & \text { probability of process in control state } 2 \\ \beta & \text { Probability of process in control state } 2 \\ \tau & \text { time taken for assignable cause to occurs } \\ \text { T1 } & \text { in control period } \\ \text { T2 } & \text { time period until the assignable is detected for the first time } \\ \text { T3 } & \text { time required to investigate the true alarm } \\ \text { T4 } & \text { time to correct the assignable cause }\end{array}$

\subsection{Description of the model}

Son and Lie (1991) considered a small manufacturing system which consists of a machining area (sampling inspection) and a final inspection area (100\% inspection) as indicated in Figure 1. However; they assume that $100 \%$ inspection is not always possible. They explained that a complete check of a component part may require the part removal from the fixture; the removal makes it difficult to realign the part to its original position.

Therefore, they assume that sampling inspection is assumed for component parts (inprocess inspection), and $100 \%$ inspection for finished parts (final inspection). Throughout the machining process, the feature of the product quality is monitored by an $\mathrm{x}$-bar chart which consists of a center line, lower, limit and an upper limit. A sample size in use is taken and inspected at a specific time interval. During machine process, when the sample mean fall outside of the control limit in the $\mathrm{x}$-bar chart, an investigation is made during an average time period to check if the alarm is true or false. The false alarm occurs if the process is in 
Sampling inspection $\quad 100 \%$ inspection

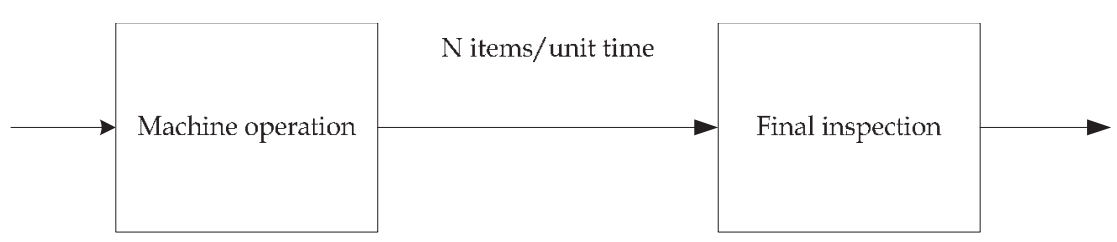

Prevention cost occurs

Failure cost occurs

Fig. 1. Simplified manufacturing system.

control and on the other hand, the true alarm occurs if an assignable cause of specific magnitude makes the process out of control. In their modelling, first they calculate the cycle time, and then quality cost (prevention and failure) per cost was determined. In the next section, equations for all components are stated, obviously, readers interested in the detail steps of deriving these equations should referred to the original article.

\subsubsection{Cycle time calculations}

The assignable cause occurs according to the Poisson process with mean rate $\Theta$. The period of the process is in control is represented by $\mathrm{T}_{1}$. $\mathrm{T}_{1}$ follows an exponential distribution with mean $1 / \Theta$.

The expected length of a cycle;

$$
\mathrm{E}\left(\mathrm{T}_{\mathrm{c}}\right)=\mathrm{E}\left(\mathrm{T}_{1}\right)+\mathrm{E}\left(\mathrm{T}_{2}\right)+\mathrm{E}\left(\mathrm{T}_{3}\right)+\mathrm{E}\left(\mathrm{T}_{4}\right)
$$

Which can be obtained using equation 2

$$
=1 / \Theta+(t+t \Gamma /(1-\beta)-\tau)+\left(g n+d_{1}\right)+d_{2}
$$

\subsubsection{Prevention cost per cycle}

There are three types of prevention costs that occur at the machining area during a cycle of time. The first cost is associated with inspection works and denoted as $\left(C_{\mathrm{p} 1}\right)$, the second cost is representing the cost of investigating the false alarms $\left(\mathrm{C}_{\mathrm{p} 2}\right)$, and the third cost is associated with adjusting the assignable cause $\left(C_{p 3}\right)$. Then, the expected prevention cost per cycle $\left(C_{p}\right)$ can be determined by summing up these three components as in equation 3 .

$$
\mathrm{E}\left(\mathrm{C}_{\mathrm{p}}\right)=\mathrm{E}\left(\mathrm{C}_{\mathrm{p} 1}\right)+\mathrm{E}\left(\mathrm{C}_{\mathrm{p} 2}\right)+\mathrm{E}\left(\mathrm{C}_{\mathrm{p} 3}\right)
$$

\subsubsection{Failure cost per cycle}

The failure cost has three components; the first component is the cost of rework per cycle $\left(\mathrm{C}_{\mathrm{f} 1}\right)$, the second component is the scrap cost per cycle $\left(\mathrm{C}_{\mathrm{f} 2}\right)$ and the third component is the external failure cost during a cycle of time $\left(\mathrm{C}_{\mathrm{f}}\right)$. Then, the expected failure cost per cycle $\left(\mathrm{C}_{\mathrm{F}}\right)$ can be determined by summing up these three components as in equation 4 .

$$
E\left(C_{F}\right)=E\left(C_{f 1}\right)+E\left(C_{f 2}\right)+E\left(C_{f 3}\right)
$$




\subsubsection{Acceptance sample cost per cycle}

Costs associated with sampling inspections prior entering the manufacturing system are not considered in the model developed by Son and Lie (1991). Our idea consists of the fact that companies often receive a shipment of material from a supplier and need to ascertain that the quality of the shipment. If it is impractical to inspect every item in the shipment, then a sampling plan is the $(n, c)$ is used. In this plan, $n$ items are chosen (without replacement) from a batch of shipped material. If $c$ or fewer of the sample items are defective, then the batch is accepted; otherwise, the batch is rejected. Therefore, there will be a cost incurred during inspection of the sample before entering the manufacturing system. The expected number of samples entering the manufacturing system is $n$ whereas $t_{o}$ is representing the time taken to inspect the sample. Let $\left(\mathrm{C}_{\mathrm{aS}}\right)$ be the cost of investigating acceptance sampling during a cycle of time. Then the expected cost associated with this activity is given by equation 5 .

$$
\mathrm{E}\left(\mathrm{C}_{\mathrm{A}}\right)=\mathrm{C}_{\mathrm{as}} \mathrm{nt}_{\mathrm{o}}
$$

Hence, the total cost of quality can be represented by summing up all the cost components (1) through (5) and is presented by equation 6.

$$
\mathrm{E}\left(\mathrm{C}_{\mathrm{Q}}\right)=\mathrm{E}\left(\mathrm{C}_{\mathrm{P}}\right)+\mathrm{E}\left(\mathrm{C}_{\mathrm{F}}\right)+\mathrm{E}\left(\mathrm{C}_{\mathrm{A}}\right)
$$

Where $E\left(C_{P}\right)$ is representing the prevention cost, $E\left(C_{F}\right)$ is representing the failure costs and $\mathrm{E}\left(\mathrm{C}_{\mathrm{A}}\right)$ is representing the acceptance sampling costs.

\section{The problem and solution methodology}

The improvement made to the cost of quality model developed by Son and Lie (1991) that was described in section 3.1.4 adds acceptance sampling plans. Almost all quality control managers in the manufacturing firms develop and implement such plans. As a result an element of appraisal cost is incurred prior to the commencement of the production activities. Moreover, unlike the work reported by Son and Lie (1991) that consider a single stage manufacturing system, this research work considers a two-stage manufacturing system.

Therefore, the problem considered by this chapter can be described as: : a manufacturing system that consists of two stages, incoming raw materials inspection carried out according to some quality plan and as a result an element of appraisal cost in incurred prior to the commencement of the production activity. Once orders are realized by the company, raw materials are brought into the shop floor and at this stage; preventive and failure costs are incurred. In order to investigate the cost of quality for this manufacturing system, we have adopted the four strategies for inspection and removal of defectives across a range of detection rates reported by Gardner et.al (1995). The strategies are summarized in the following manner:

1. Inspection and removal of defectives based on acceptance sampling prior to assembly points

2. Inspection and removal of defectives at completion of finished product only,

3. Inspection and removal of defectives prior to assembly points,

4. Inspection and removal of defectives following every operations, and

The motivation for creating the above strategies (quality control decisions) and then using simulation tool is to investigate the impact of these strategies on cost of quality. One may conclude that the result of implementing any of these decisions is obvious. For example, the 
strategy that calls to carry out the inspection works at the final stage of the production and then removal of defectives will minimize the inspection costs, however, the increase of defectives at the final stage of manufacturing is inevitable. Moreover, inspection and removal of defectives prior to the assembly line will increase the quality prevention cost component and indirectly reduce the failure cost component. However, without the development of the cost of quality model and the simulation works, the magnitude of cost of quality could not be determined and the impact would not be known. It is not a secret that many firms sacrifices parts of the quality control steps under pressure to reduce cycle time.

Once the cost of quality model and its three components is developed, a simulation model using @Risk spreadsheet simulation software is developed for the two-stage process. The popularity using spreadsheet technology among practitioners justifies the use of the proposed @Risk simulation software.

\section{Experiment design}

Inspection time was considered as the main factor for calculating cost of quality. This is important as in real-life manufacturing systems; production line managers consider cycle time to be an important factor. Moreover, quite often, quality control activities or part of the activities would be sacrificed in order to attain a desired cycle time.

In order to simplify the experiment, it was decided to use the same fractions of defective rate to every operation in the manufacturing system for a given trial. The fractions of defective rate are divided into five categories: .001, 0.005, 0.010, 0.050 and 0.100. Every trial will run for about 10000 times of the simulation runs as indicated in Table 2.

\begin{tabular}{|l|l|l|l|l|l|}
\hline $\begin{array}{l}\text { Inspection and } \\
\text { defective removal } \\
\text { strategies }\end{array}$ & \multicolumn{5}{|l|}{ Fraction Detection per Operation } \\
\cline { 2 - 6 } & 0.001 & 0.005 & 0.01 & 0.05 & 0.1 \\
\hline $\begin{array}{l}\text { Acceptance } \\
\text { sampling }\end{array}$ & $\begin{array}{l}10000 \\
\text { run }\end{array}$ & $\begin{array}{l}10000 \\
\text { run }\end{array}$ & $\begin{array}{l}10000 \\
\text { run }\end{array}$ & $\begin{array}{l}10000 \\
\text { run }\end{array}$ & $\begin{array}{l}10000 \\
\text { run }\end{array}$ \\
\hline $\begin{array}{l}\text { Completion of } \\
\text { finish product }\end{array}$ & $\begin{array}{l}10000 \\
\text { run }\end{array}$ & $\begin{array}{l}10000 \\
\text { run }\end{array}$ & $\begin{array}{l}10000 \\
\text { run }\end{array}$ & $\begin{array}{l}10000 \\
\text { run }\end{array}$ & $\begin{array}{l}10000 \\
\text { run }\end{array}$ \\
\hline Prior to assembly & $\begin{array}{l}10000 \\
\text { run }\end{array}$ & $\begin{array}{l}10000 \\
\text { run }\end{array}$ & $\begin{array}{l}10000 \\
\text { run }\end{array}$ & $\begin{array}{l}10000 \\
\text { run }\end{array}$ & $\begin{array}{l}10000 \\
\text { run }\end{array}$ \\
\hline $\begin{array}{l}\text { Following every } \\
\text { operation }\end{array}$ & $\begin{array}{l}10000 \\
\text { run }\end{array}$ & $\begin{array}{l}10000 \\
\text { run }\end{array}$ & $\begin{array}{l}10000 \\
\text { run }\end{array}$ & $\begin{array}{l}10000 \\
\text { run }\end{array}$ & $\begin{array}{l}10000 \\
\text { run }\end{array}$ \\
\hline
\end{tabular}

Table 2. Experiment design for simulation run.

Therefore there will be twenty combinations of strategies and defective rates. All the combinations will run for 10000 iterations each. It is worth to note that during the design of the sampling acceptance procedure, it was assumed that the company would receives a batch of 10,000 items which require assembly activities using processes one and two respectively. Moreover, it is assumed that the quality engineers have developed a quality plan which is described as the (n, c) plan. In an (n, c) plan, n items are chosen (without replacement) from the batch of shipped material whereas $c$ is the maximum number of defective items that a sample could have. If the number of the defective items in the sample is fewer or equal to $c$, then the batch is accepted otherwise the batch is rejected. For example, 
in process 1 , a sample of 90 items will be inspected and the entire 1000 items are accepted if $0,1,2,3,4$, or 5 defective items are found in the sample otherwise the batch is rejected.

On the other hand, for process 2, a sample of 40 items will be inspected and the entire batch will be accepted if $0,1,2$ or 3 defective items are found in the sample otherwise the batch will be rejected. The idea here is to set the Actable Quality Level (AQL) to be equal to 1\% and the Lot Tolerance Percentage Defective (LTPD) to be equal to 5\%. Once AQL and the LTPD are set, a simulation run is carried out to determine the cost of quality associated with the quality control strategies (decisions) detailed in section 4 in this chapter. It is worth noting and as indicated earlier, the process under consideration consists of two processes. In order to avoid computational complexities; it was decided to apply and conduct simulation runs for each management strategies to each process separately and then combined the two processes to examine the overall findings. The numerical values which were used in the simulation model are portrayed in Tables 3 and 4.

\begin{tabular}{|c|c|c|c|}
\hline \multirow{2}{*}{ Manufacturing system } & & Process 1 & Process 2 \\
\hline & Symbol & Value & Value \\
\hline $\begin{array}{l}\text { Average number of assignable cause per } \\
\text { hour }\end{array}$ & $\Theta$ & 0.001 & 0.001 \\
\hline Lower specification level & LSL & 0.79 & 0.99 \\
\hline Upper specification level & USL & 0.81 & 1.01 \\
\hline Average height of the product population & $\mu$ & 0.80 & 1.00 \\
\hline $\begin{array}{l}\text { Standard deviation of the product } \\
\text { population }\end{array}$ & $\sigma$ & 0.007 & 0.015 \\
\hline Magnitude of an assignable cause & $\delta$ & 5 & 7 \\
\hline Value to decide control limit & $q$ & 3 & 7 \\
\hline Sampling interval & $\mathrm{t}$ & 5 & 20 \\
\hline Sample size per sampling & $\mathrm{n}$ & 90 & 40 \\
\hline $\begin{array}{l}\text { Mean time spent to identify an assignable } \\
\text { cause }\end{array}$ & $\mathrm{d}_{1}$ & 0.5 & 0.5 \\
\hline $\begin{array}{l}\text { Mean time spent to correct an assignable } \\
\text { cause }\end{array}$ & $\mathrm{d}_{2}$ & 2 & 2.5 \\
\hline Time required to sample a product & $\mathrm{g}$ & 0.05 & 10 \\
\hline
\end{tabular}

Table 3. Numeric values for processes 1 and 2.

Strategy 1. Inspection and removal of defectives based on acceptance sampling prior to assembly points.

This quality control strategy calls for the removal of defectives at the sampling stage and no quality control to be conducted after that stage. The total cost of quality associated with this strategy would be determined based on the following equation:

$$
\mathrm{TCOQ}_{1}=\mathrm{C}_{\mathrm{as}} \mathrm{nt}_{\mathrm{o}}
$$




\begin{tabular}{|l|l|l|l|}
\hline \multirow{2}{*}{ Manufacturing system } & & Process 1 & Process 2 \\
\cline { 2 - 4 } & Symbol & Value & Value \\
\hline $\begin{array}{l}\text { Number of products produced at the } \\
\text { machining area per hour }\end{array}$ & $\mathrm{N}$ & 40 & 20 \\
\hline $\begin{array}{l}\text { Error rate of misclassifying a good part into } \\
\text { bad }\end{array}$ & $\mathrm{e}_{1}$ & 0.01 & 0.01 \\
\hline $\begin{array}{l}\text { Error rate of misclassifying a bad part as } \\
\text { good }\end{array}$ & $\mathrm{e}_{2}$ & 0.005 & 0.005 \\
\hline Rate of restoring a defect to a good part & $\mathrm{w}$ & 0.95 & 0.95 \\
\hline Fixed sampling cost per sampling interval & $\mathrm{a}_{1}$ & 25 & 30 \\
\hline Variable sampling cost per unit product & $\mathrm{a}_{2}$ & 8 & 5 \\
\hline Cost of investigating a false alarm & $\mathrm{C}_{\mathrm{fs}}$ & 80 & 80 \\
\hline Cost of correcting an assignable cause & $\mathrm{C}_{\mathrm{cr}}$ & 150 & 150 \\
\hline $\begin{array}{l}\text { Cost of reworking a good part because of } \\
\text { misclassification }\end{array}$ & $\mathrm{C}_{\mathrm{g}}$ & 100 & 100 \\
\hline Cost of reworking a defective part & $\mathrm{C}_{\mathrm{b}}$ & 200 & 200 \\
\hline $\begin{array}{l}\text { Cost of scrapping a defective part that } \\
\text { cannot be restored }\end{array}$ & $\mathrm{C}_{\mathrm{s}}$ & 75 & 75 \\
\hline $\begin{array}{l}\text { Cost of dissatisfying a customer by selling a } \\
\text { defective part }\end{array}$ & $\mathrm{C}_{\mathrm{a}}$ & 100 & 100 \\
\hline
\end{tabular}

Table 4. Numeric values for processes 1 and 2.

Strategy 2. Inspection and removal of defectives at completion of finished product only.

This strategy calls for inspection of items among completion of the two processes. Therefore, it means that there will be no quality control during the process of making the products. Hence, the cost of quality that will be incurred in this strategy is meanly failure costs. However, it is assumed here that samples have to undergo visual inspection before the items enter into the manufacturing system. Therefore, the total costs of quality associates on this strategy are;

$$
\mathrm{TCOQ}_{1}=\mathrm{E}\left(\mathrm{C}_{\mathrm{A}}\right)+\mathrm{E}\left(\mathrm{C}_{\mathrm{F}}\right)=\mathrm{E}\left(\mathrm{C}_{\mathrm{A}}\right)+\mathrm{E}\left(\mathrm{C}_{\mathrm{f} 1}\right)+\mathrm{E}\left(\mathrm{C}_{\mathrm{f} 2}\right)+\mathrm{E}\left(\mathrm{C}_{\mathrm{f} 3}\right)
$$

Strategy 3. Inspection and removal of defectives prior to assembly points.

This strategy requires that items must be inspected and defectives are removed prior to assembly. In this case, since the inspection is done at the end of the process, the cost of quality is simply the prevention cost which is incurred during inspection of the material. However, parts with defects could be produced since there is no quality control during and at the end of the assembly. Therefore, there will be some failure costs which is required to convert defective items into good items. Moreover, inspection costs before the items enter the manufacturing system have to be considered. Therefore, the total costs of quality associates on this strategy are;

$$
\mathrm{TCOQ}_{2}=\mathrm{E}\left(\mathrm{C}_{\mathrm{A}}\right)+\mathrm{E}\left(\mathrm{C}_{\mathrm{p} 1}\right)+\mathrm{E}\left(\mathrm{C}_{\mathrm{F}}\right)=\mathrm{E}\left(\mathrm{C}_{\mathrm{A}}\right)+\mathrm{E}\left(\mathrm{C}_{\mathrm{p} 1}\right)+\mathrm{E}\left(\mathrm{C}_{\mathrm{f} 1}\right)+\mathrm{E}\left(\mathrm{C}_{\mathrm{f} 2}\right)+\mathrm{E}\left(\mathrm{C}_{\mathrm{f} 3}\right)
$$


Strategy 4. Inspection and removal of defectives following every operations.

This strategy calls for inspection and removal of defectives following every operation. Hence, the inspection will take place at the end of every operation to determine if there are defectives and perform the necessary corrections (rework). As a result, there will be an element of failure costs. Moreover, since the system includes inspection costs before items enter the manufacturing system, an additional inspection cost will be incurred. The total costs of quality associates on this strategy are;

$$
\mathrm{TCOQ}_{3}=\mathrm{E}\left(\mathrm{C}_{\mathrm{A}}\right)+\mathrm{E}\left(\mathrm{C}_{\mathrm{p} 1}\right)+\mathrm{E}\left(\mathrm{C}_{\mathrm{p} 2}\right)+\mathrm{E}\left(\mathrm{C}_{\mathrm{F}}\right)=\mathrm{E}\left(\mathrm{C}_{\mathrm{A}}\right)+\mathrm{E}\left(\mathrm{C}_{\mathrm{p} 1}\right)+\mathrm{E}\left(\mathrm{C}_{\mathrm{p} 2}\right)+\mathrm{E}\left(\mathrm{C}_{\mathrm{f} 1}\right)+\mathrm{E}\left(\mathrm{C}_{\mathrm{f} 2}\right)+\mathrm{E}\left(\mathrm{C}_{\mathrm{f} 3}\right)
$$

Each mathematical model that describe each strategy is developed in MS Excel spreadsheet for each process separately and then for the combinations of the two stages. The simulation software @Risk is imbedded and a simulation of 10000 iterations is carried out. This way, the impact of each of the strategy can be investigated and the impact on cost of quality can be determined.

\section{Model verification, results and discussions}

\subsection{Model verification}

A problem of model verifications arises when using simulation approach in decision evaluation. The literature referred to model verifications procedure developed by Naylor and Finger (1967) that ensures the developed model is free from any illogical error. In order to accomplish the task, the formulation and its parameters provided by Son and Lie (1991) were used to compute the prevention and failure costs reported by the authors. A simulation run was carried out and the results of the simulation model were compared with the results reported by Son and Lie (1991). The results are presented in Table 5.

\begin{tabular}{|c|c|c|c|c|c|}
\hline \multicolumn{3}{|c|}{ Son and Lie (1991) results } & \multicolumn{3}{|c|}{ The Simulation results } \\
\hline $\begin{array}{c}\text { Total } \\
\text { length of } \\
\text { a cycle, } \mathrm{T}_{\mathrm{C}} \\
\text { (hours) }\end{array}$ & $\begin{array}{l}\text { Prevention } \\
\text { cost per } \\
\text { cycle, } C_{P}(\$)\end{array}$ & $\begin{array}{c}\text { Failure cost } \\
\text { per cycle, } \\
C_{F}(\$)\end{array}$ & $\begin{array}{c}\text { Total } \\
\text { length of a } \\
\text { cycle, } \mathrm{T}_{\mathrm{C}} \\
\text { (hours) }\end{array}$ & $\begin{array}{l}\text { Prevention } \\
\text { cost per } \\
\text { cycle, } C_{P}(\$)\end{array}$ & $\begin{array}{c}\text { Failure cost } \\
\text { per cycle, } \\
C_{F}(\$)\end{array}$ \\
\hline $\mathrm{E}\left[\mathrm{T}_{1}\right]=$ & $\mathrm{E}\left(\mathrm{C}_{\mathrm{P} 1}\right]=$ & $\mathrm{E}\left(\mathrm{C}_{\mathrm{F} 1}\right]=$ & $\mathrm{E}\left[\mathrm{T}_{1}\right]=$ & $\mathrm{E}\left(\mathrm{C}_{\mathrm{P} 1}\right]=$ & $\mathrm{E}\left(\mathrm{C}_{\mathrm{F} 1}\right]=$ \\
\hline 100.00 & $\$ 312.83$ & $\$ 3292.96$ & 100 & $\$ 312.83$ & $\$ 3292.96$ \\
\hline $\begin{array}{c}\mathrm{E}\left[\mathrm{T}_{2}\right]= \\
4.28\end{array}$ & $\begin{array}{c}\mathrm{E}\left[\mathrm{C}_{\mathrm{P} 2}\right]= \\
\$ 2.63\end{array}$ & $\begin{array}{l}\mathrm{E}\left[\mathrm{C}_{\mathrm{F} 2}\right]= \\
\$ 214.21\end{array}$ & $\mathrm{E}\left[\mathrm{T}_{2}\right]=4.28$ & $\begin{array}{c}\mathrm{E}\left[\mathrm{C}_{\mathrm{P} 2}\right]= \\
\$ 2.63\end{array}$ & $\begin{array}{l}\mathrm{E}\left[\mathrm{C}_{\mathrm{F} 2}\right]= \\
\$ 214.21\end{array}$ \\
\hline $\begin{array}{c}\mathrm{E}\left[\mathrm{T}_{3}\right]= \\
0.55\end{array}$ & $\begin{array}{l}\mathrm{E}\left[\mathrm{C}_{\mathrm{P} 3}\right]= \\
\$ 100.00\end{array}$ & $\begin{array}{c}\mathrm{E}\left[\mathrm{C}_{\mathrm{F} 3}\right]= \\
\$ 32.29\end{array}$ & $\begin{array}{c}\mathrm{E}\left[\mathrm{T}_{3}\right]= \\
0.55\end{array}$ & $\begin{array}{l}\mathrm{E}\left[\mathrm{C}_{\mathrm{P} 3}\right]= \\
\$ 100.00\end{array}$ & $\begin{array}{c}\mathrm{E}\left[\mathrm{C}_{\mathrm{F} 3}\right]= \\
\$ 32.29\end{array}$ \\
\hline $\begin{array}{c}\mathrm{E}\left[\mathrm{T}_{4}\right]= \\
2\end{array}$ & & & $\begin{array}{c}\mathrm{E}\left[\mathrm{T}_{4}\right]= \\
2\end{array}$ & & \\
\hline $\begin{array}{l}E\left[T_{C}\right]= \\
106.83\end{array}$ & $\begin{array}{c}E\left[C_{P}\right]= \\
\$ 415.46\end{array}$ & $\begin{array}{c}E\left[C_{F}\right]= \\
\$ 3539.46\end{array}$ & $\begin{array}{l}\mathrm{E}\left[\mathrm{T}_{\mathrm{C}}\right]= \\
106.83\end{array}$ & $\begin{array}{c}E\left[C_{P}\right]= \\
\$ 415.46\end{array}$ & $\begin{array}{c}E\left[C_{F}\right]= \\
\$ 3359.46\end{array}$ \\
\hline
\end{tabular}

Table 5. Comparison results.

Table 5 indicates that the results obtained from the simulation model match exactly the results reported by Son and Lie (1991). The results from this finding indicate that the simulation model is an accurate presentation of that reported by Son and Lie (1991). Hence, it is concluded that the model is ready for investigation the evaluating the quality control decisions. 


\subsection{Results and discussions}

\subsubsection{Acceptance sampling prior to assembly points}

As indicted earlier, the quality control engineers develop quality control plan.

In this inspection as mentioned in section 4, the quality control engineers have developed a quality control plan based on the concept of producer's risk which is related to acceptable quality level (AQL) and the consumer's risk which is related to tolerance percentage defective (LTPD).

The summary of the statistics that resulted from the simulations runs shows that the mean was found to be equal to 0.994 with a tile of $15 \%$ and the maximum is equal to 1 with a tile of $5 \%$. Since it was concluded that the sample is good, since $99.94 \%$ of the sample is within $1 \%$ of defectives, then the items are considered to be acceptable. On the other hand, the remaining $0.06 \%$ of the sample contributes to produce risk. This means that the plan has a risk of losing $0.06 \%$ of good sample. It is worth noting that the skewness has a negative value that is -40.7941969 indicating that distribution of the sample exceedingly to the left.

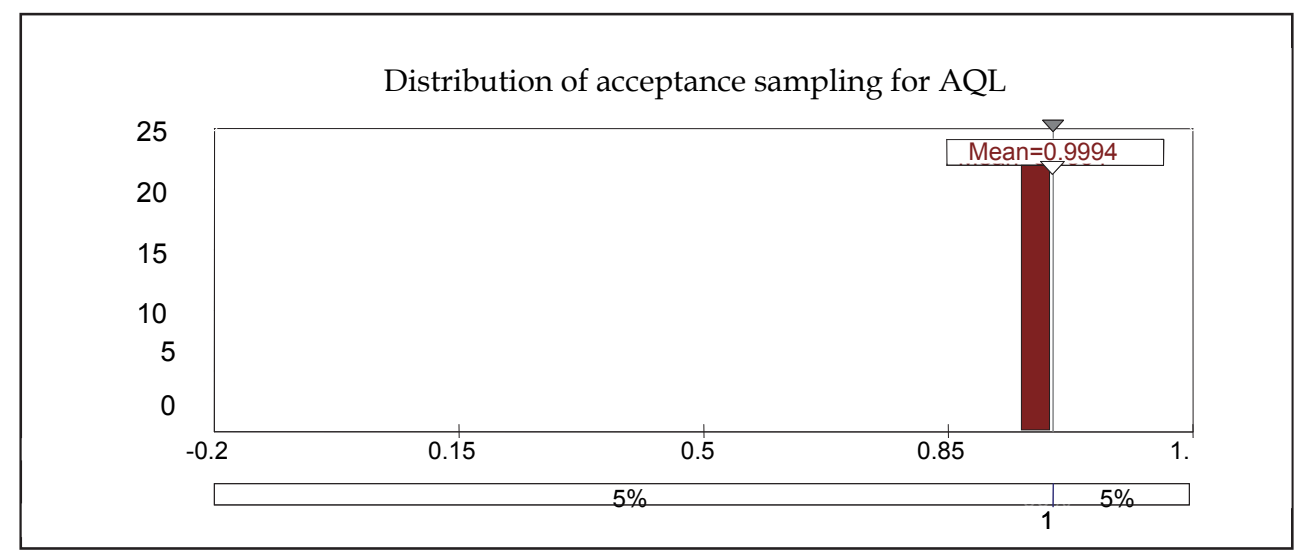

Fig. 2. Distribution of acceptance sampling for AQL.

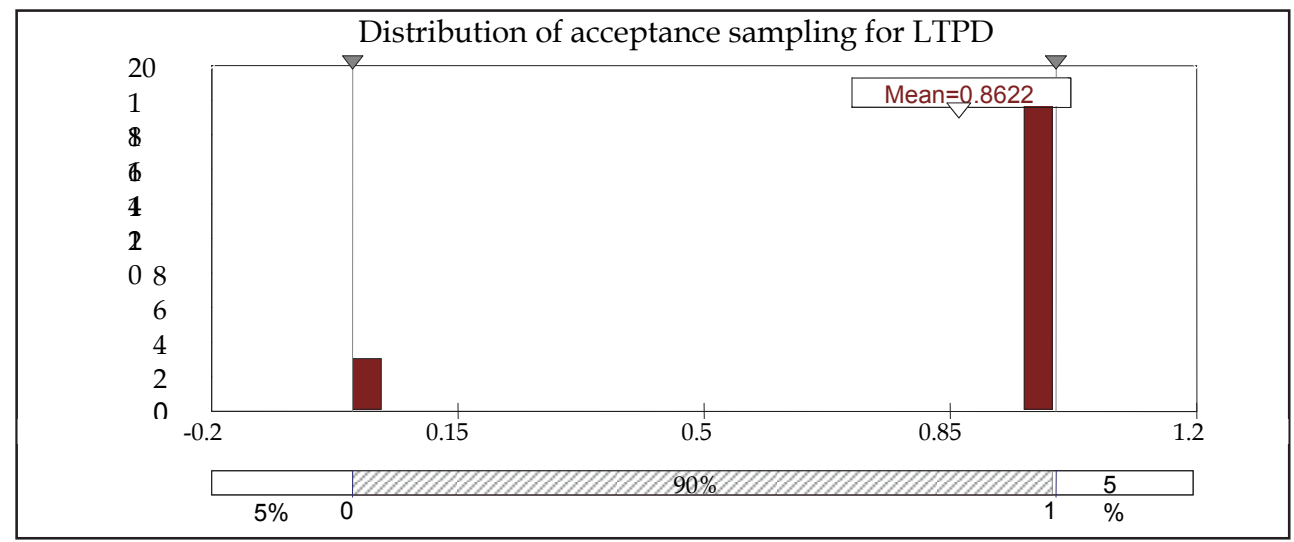

Fig. 3. Distribution of acceptance sampling for LTPD. 
Figure 2 was constructed to display the summary statistics, the mean value for the acceptable quality level (AQL) over the tile percentage. From the chart it could be seen that the mean of the sample is equal to 0.9994 which very close to the value of 1 which indicate that the risk is equal to 0.00006 .

As for the risk associated with low tolerance percentage defect (LTPD), the statistics summary results indicate that the mean has a value of 0.8622 which says that $86.22 \%$ of the sample size has defects and would be accepted as good parts. Therefore, such situation indicates that the risk would be about $86.22 \%$ of the sampling plan. Figure 3 summarizes the summary statistics. In Figure 3, the distribution is skewed towards the right represents the lot tolerance percentage defects with a mean of $86.22 \%$.

\subsubsection{Inspection upon completion of assembly}

In this case inspection and removal will took place upon completion of assembly activities. Simulation runs resulted in obtaining the cost of quality associated with strategy of inspection upon completion of assembly activities at each level of defects rate per operation is presented in Table 6 .

\begin{tabular}{|c|c|c|c|c|c|}
\hline \multicolumn{6}{|c|}{ Cost of Quality (x 1000) } \\
\hline \multirow{2}{*}{$\begin{array}{c}\text { Defective rate } \\
\text { per operation } \\
(\%)\end{array}$} & \multicolumn{5}{|c|}{ Time interval ( $\mathrm{t}, \mathrm{hr}$ ) and time inspection of a product $(\mathrm{g}, \mathrm{hr})$, Cost is in } \\
\cline { 2 - 6 } & $\mathrm{t}=20$ & $\mathrm{t}=17$ & $\mathrm{t}=15$ & $\mathrm{t}=10$ & $\mathrm{t}=8$ \\
$\mathrm{~g}=8$ & $\mathrm{~g}=7$ & $\mathrm{~g}=6$ \\
\hline 0.001 & 3558.95 & 3398.49 & 3239.98 & 3075.65 & 2917.15 \\
\hline 0.005 & 1989.88 & 1829.28 & 1670.68 & 1506.19 & 1347.65 \\
\hline 0.01 & 1794.33 & 1633.55 & 1474.85 & 1310.16 & 1151.55 \\
\hline 0.05 & 1642.42 & 1480.26 & 1320.76 & 1154.48 & 995.41 \\
\hline 0.10 & 1628.56 & 1464.93 & 1304.54 & 1136.43 & 976.81 \\
\hline
\end{tabular}

Table 6. Cost of quality at different values of defect rate, time interval and inspection time.

Table 6 reveals the total cost of quality is decreasing as we move towards the right side of the table. The reason for that is the fact that the more time is allocated for inspection work, the more of the defects will be found. This finding could be seen for example when considering the total cost at 0.001 defects rate at interval time of 20 hours and inspection time for 10 hours. Considering that example reveals that the cost has decrease by $27 \%$. Moreover, Table 6 indicates that the maximum impact on total cost of quality resulted from implanting this strategy occurred at defect rate 0.001 with time equal to 20 hours and inspection time of 10 hours. On the other hand, the minimum cost of quality occurs at a defect rate of 0.10 with 8 hours interval time of inspection. The total cost of quality behaviour at various interval times for each defect rate is presented in Figure 4.

Figure 4 reveals that there is a large gap between the curve for the defects rate at 0.001 and the curve represents the defect rate at 0.005 . As it could be seen, there is a drastic drop and the drop is due to the increase of the defects that will cause the time taken to inspect the defect is shorter and thus the time to correct the assignable cause shorter. Hence, it will reduce the total cost of quality in this situation compared to the lower defect rate. Moreover, the difference of the total cost of quality at defect rate of 0.05 and defect rate of 0.10 is small. Therefore, the curves represent this defect rate is overlapping with each other's and the curve that represents the defect rate of 0.10 has the smallest total cost of quality. 
Total cost of quality behaviour at various interval times for each defect

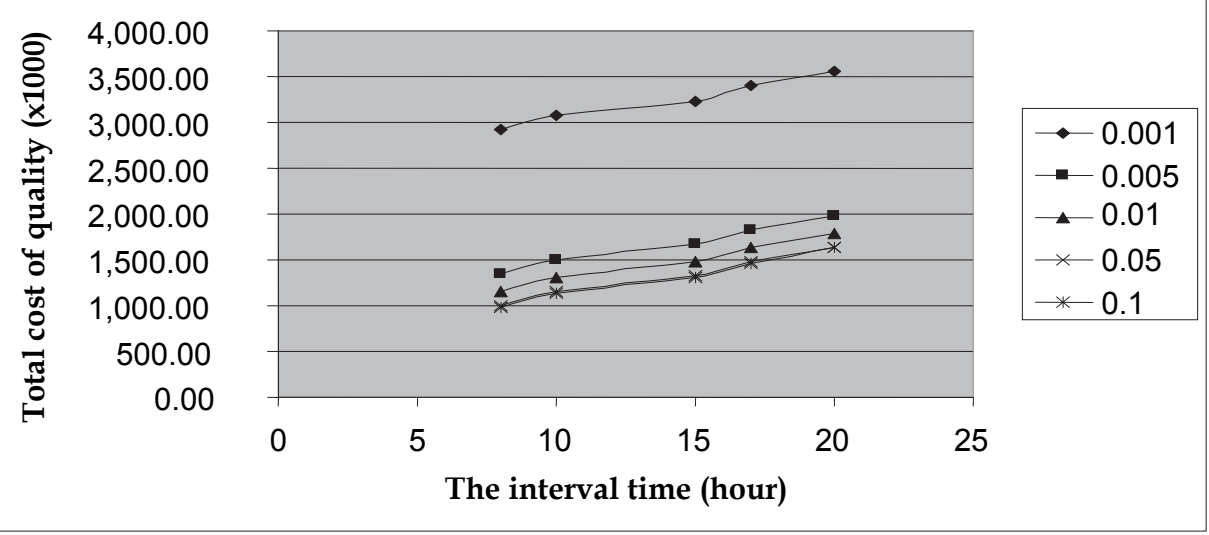

Fig. 4. Cost of quality behaviour at various interval times for each defect rate.

\subsubsection{Inspection prior to assembly operations}

This quality control strategy calls for inspection to be carried out at the commencement of the assembly process; the cost of quality at various defective rates and inspection interval times is presented in Table 7.

\begin{tabular}{|c|c|c|c|c|c|}
\hline \multicolumn{6}{|c|}{ Cost of Quality (x 1000) } \\
\hline \multirow{3}{*}{$\begin{array}{c}\text { Defective rate } \\
\text { per operation } \\
(\%)\end{array}$} & \multicolumn{5}{|c|}{ Time interval ( $\mathrm{t}, \mathrm{hr}$ ) and time inspection of a product (g, hr), Cost is in } \\
\cline { 2 - 6 } & $\mathrm{t}=20$ & $\mathrm{t}=17$ & $\mathrm{t}=15$ & $\mathrm{t}=10$ & $\mathrm{t}=8$ \\
$\mathrm{~g}=10$ & $\mathrm{~g}=9$ & 2803 & $\mathrm{~g}=6$ \\
\hline 0.001 & 3073.71 & 2937.75 & 2803 & 2669.58 & 2539.01 \\
\hline 0.005 & 1715.11 & 1577.40 & 1441.37 & 1301.44 & 1166.24 \\
\hline 0.01 & 1545.79 & 1407.72 & 1271.42 & 1130.55 & 994.72 \\
\hline 0.05 & 1414.24 & 1274.82 & 1137.69 & 994.84 & 858.15 \\
\hline 0.10 & 1402.23 & 1261.52 & 1123.60 & 979.09 & 841.87 \\
\hline
\end{tabular}

Table 7. Cost of quality at different values of defect rate, time interval and inspection time.

Table 7 reveals that the maximum total cost of quality occurs at defect rate of 0.001 and time interval of 20 hours and inspection time of 10 hours. On the other hand, the minimum total cost of quality occurs at defective rate of .10, time interval of 8 hours and inspection time of 6 hours. As it could be noticed that as the time of inspection become shorter, total cost of quality is reduced. The relationship between total cost of quality, the time interval and defective rate is presented in Figure 5. 


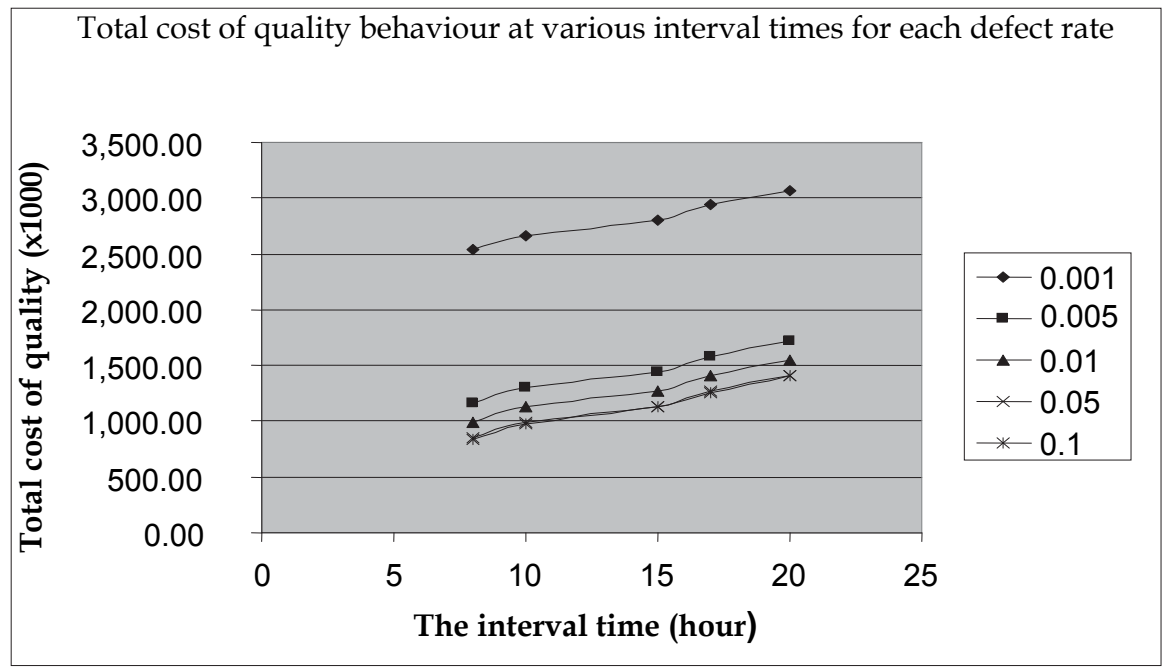

Fig. 5. Cost of quality behaviour at various interval times for each defect rate.

\subsubsection{Inspection following every assembly operations}

This strategy calls for inspection works to be carried out at the end of the process for every operation. The cost of quality at various defective rates and inspection interval times is presented in Table 8.

\begin{tabular}{|c|c|c|c|c|c|}
\hline \multicolumn{6}{|c|}{ Cost of Quality (x 1000) } \\
\hline \multirow{3}{*}{$\begin{array}{c}\text { Defective rate } \\
\text { per operation } \\
(\%)\end{array}$} & $\begin{array}{c}\text { Time interval ( } \mathrm{t}, \mathrm{hr} \text { ) and time inspection of a product (g, hr), Cost is in } \\
\text { MU = Monetary Unit }\end{array}$ \\
\cline { 2 - 6 } & $\mathrm{g}=10$ & $\begin{array}{c}\mathrm{t}=17 \\
\mathrm{~g}=9\end{array}$ & $\begin{array}{c}\mathrm{t}=15 \\
\mathrm{~g}=8\end{array}$ & $\begin{array}{c}\mathrm{t}=10 \\
\mathrm{~g}=7\end{array}$ & $\begin{array}{c}\mathrm{t}=8 \\
\mathrm{~g}=6\end{array}$ \\
\hline 0.001 & 3062.25 & 2924.25 & 2787.93 & 2646.61 & 2510.30 \\
\hline 0.005 & 1712.85 & 1574.73 & 1438.34 & 1296.88 & 1160.53 \\
\hline 0.01 & 1544.67 & 1406.40 & 1269.92 & 1128.29 & 991.88 \\
\hline 0.05 & 1414.03 & 1274.57 & 1137.40 & 994.40 & 857.61 \\
\hline 0.10 & 1402.11 & 1261.39 & 1123.45 & 978.88 & 841.60 \\
\hline
\end{tabular}

Table 8. Cost of quality at different values of defect rate, time interval and inspection time.

Table 8 reveals that the maximum total cost of quality occurs at defective rate of 0.001 , interval time of 20 hours and inspection time of 10 hours. On the other hand, the minim total cost of quality occurs at defective rate of 0.10 , time interval of 8 hours and inspection time of 6 hours.. The relationship between total cost of quality, the time interval and defective rate is presented in Figure 6. 


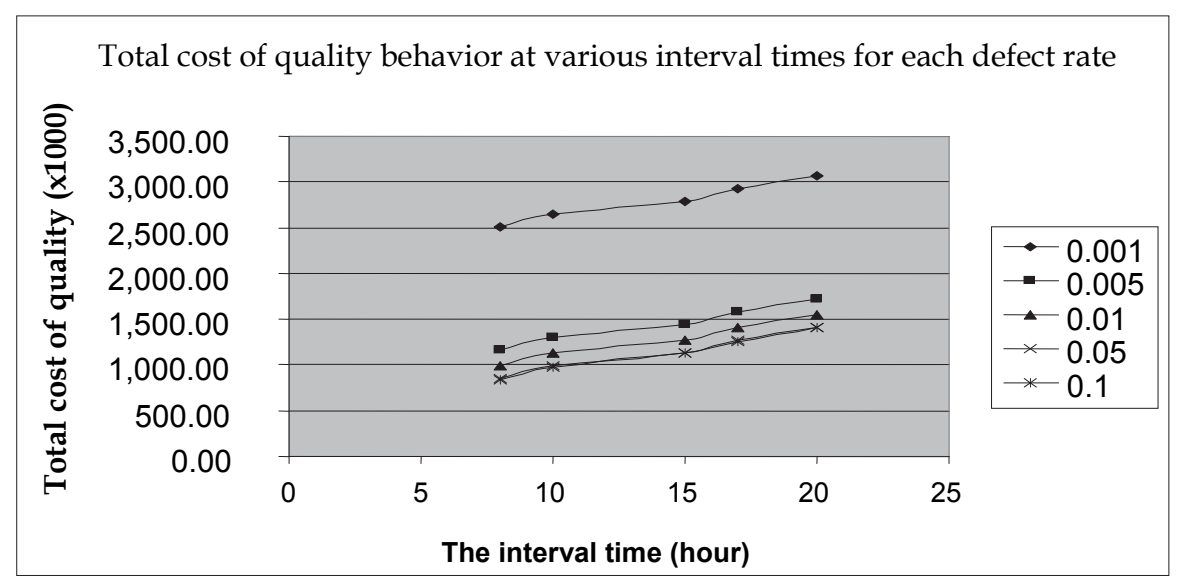

Fig. 6. Cost of quality behaviour at various interval times for each defect rate.

Figure 6 reveals that as defective rate per operation is increased, the total cost of quality decreases. This is because as the defective rate is increased, the time taken to detect the defect becomes shorter. Hence, the time taken to convert the process out of control to in control state will be shorter and finally the impact of cost of quality will be smaller.

In order to provide a good picture to the reader, Figure 7 was developed and a graphical presentation that shows the relationship between total cost of quality, and detection rate per operation.

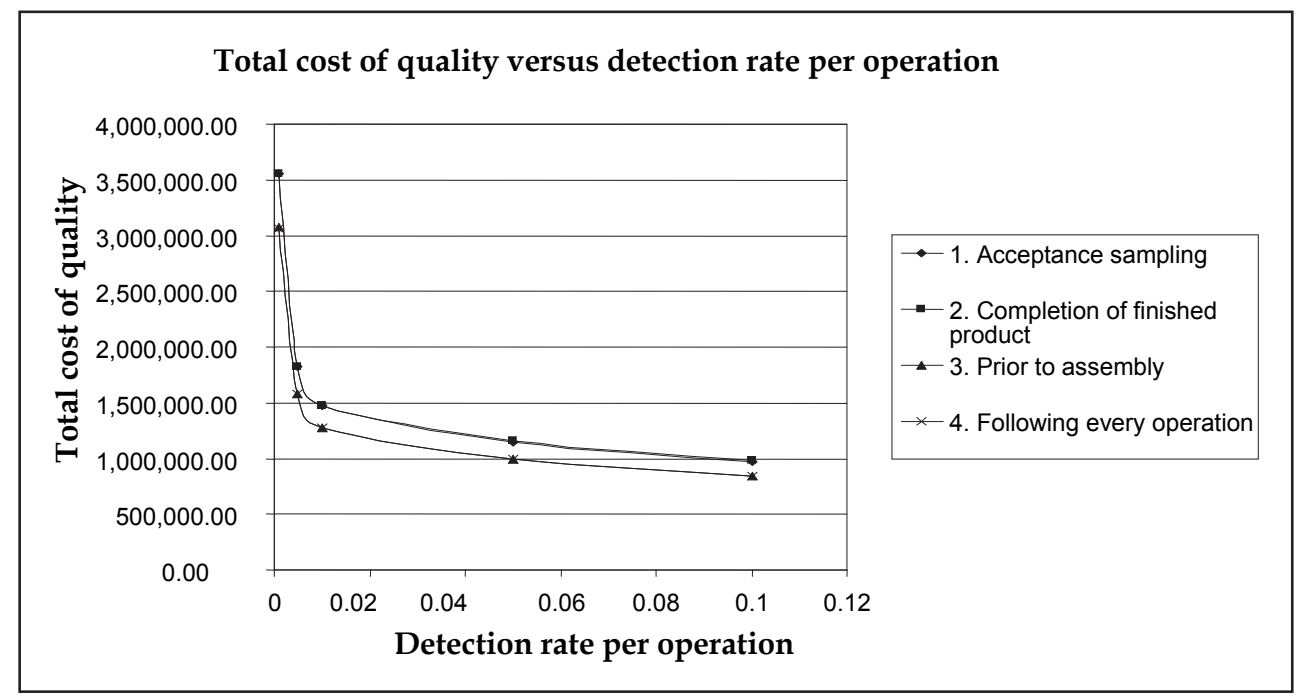

Fig. 7. Cost of quality for the four strategies.

Figure 7 indicates that total cost of quality is at its maximum value when the detection rate is zero, and then steadily decreased as the window of inspection increases. Moreover, 
inspection following every assembly operations has the lowest total cost of quality. This is because as the appraisal cost increases, the failure costs will simultaneously reduced since less defect rate occurs and hence less items is sent for rework.

\subsubsection{Investigation of strategies combination}

Since simulation modelling can provide a window of opportunity to investigate important quality control decisions and their impact on cost of quality. It is thought that the quality control management may wish to consider some combination of strategies for each process rather than having a single strategy for the whole assembly process. In this case, one has to determine the possible quality strategies combinations that could be considered for the simulation run. Let $\mathrm{R}$ be the possible strategies combination outcome, then we would have:

$$
R=\sum S_{i, j}
$$

Where

$$
\mathrm{i}=\text { A strategy in process } 1 \quad \mathrm{i}=1,2,3,4 \text { and } \mathrm{j}=\text { A strategy in process } 2 \quad \mathrm{j}=1,2,3,4
$$

\begin{tabular}{|c|c|c|c|c|c|}
\hline \multirow{2}{*}{\begin{tabular}{c} 
Inspection $\begin{array}{c}|c| \\
\text { and } \\
\text { defective } \\
\text { removal } \\
\text { strategies }\end{array}$ \\
\cline { 2 - 6 }
\end{tabular}} & 0.001 & 0.005 & 0.01 & 0.05 & 0.1 \\
\hline $\mathrm{S}_{1,1}$ & $4,845.07$ & $2,137.34$ & $1,651.57$ & $1,224.13$ & $1,023.91$ \\
\hline $\mathrm{S}_{1,2}$ & $4,854.02$ & $2,141.85$ & $1,655.16$ & $1,226.89$ & $1,026.21$ \\
\hline $\mathrm{S}_{1,3}$ & $4,368.78$ & $1,889.97$ & $1,451.73$ & $1,067.25$ & 891.27 \\
\hline $\mathrm{S}_{1,4}$ & $4,357.32$ & $1,887.30$ & $1,450.23$ & $1,066.82$ & 891.01 \\
\hline $\mathrm{S}_{2,1}$ & $4,848.23$ & $2,138.03$ & $1,651.92$ & $1,224.21$ & $1,023.93$ \\
\hline $\mathrm{S}_{2,2}$ & $4,857.18$ & $2,142.53$ & $1,655.51$ & $1,226.97$ & $1,026.23$ \\
\hline $\mathrm{S}_{2,3}$ & $4,371.95$ & $1,890.65$ & $1,452.08$ & $1,067.32$ & 891.30 \\
\hline $\mathrm{S}_{2,4}$ & $4,360.48$ & $1,887.98$ & $1,450.58$ & $1,066.89$ & 891.03 \\
\hline $\mathrm{S}_{3,1}$ & $4,622.03$ & $2,090.06$ & $1,630.57$ & $1,217.32$ & $1,023.83$ \\
\hline $\mathrm{S}_{3,2}$ & $4,630.98$ & $2,094.56$ & $1,634.16$ & $1,220.08$ & $1,026.13$ \\
\hline $\mathrm{S}_{3,3}$ & $4,145.74$ & $1,842.68$ & $1,430.73$ & $1,060.44$ & 891.20 \\
\hline $\mathrm{S}_{3,4}$ & $4,134.28$ & $1,840.00$ & $1,429.23$ & $1,060.01$ & 890.93 \\
\hline $\mathrm{S}_{4,1}$ & $4,472.97$ & $2,052.62$ & $1,605.53$ & $1,209.65$ & $1,016.16$ \\
\hline $\mathrm{S}_{4,2}$ & $4,481.93$ & $2,057.12$ & $1,609.12$ & $1,212.41$ & $1,018,47$ \\
\hline $\mathrm{S}_{4,3}$ & $3,996.69$ & $1,805.25$ & $1,405.69$ & $1,052.76$ & 883.53 \\
\hline $\mathrm{S}_{4,4}$ & $3,985.23$ & $1,802.57$ & $1,404.19$ & $1,052.33$ & 883.26 \\
\hline
\end{tabular}

Table 9. Total cost of quality for the assembly system.

Table 9 shows all possible quality strategies combinations with their respective cost at each selected fraction detection rate for each operation. As it could be seen from Table 9, the combination of $\{2,2\}$ strategies have caused the system to incur the largest cost of quality. This is the case when the management decided to use the quality strategy in which quality control inspection work is only to be carried at the end of the production runs. On the other hand, one can see from Table 9 that that adopting combination of $\{4,4\}$ strategies have caused the system to incur the least cost of quality. As it could be easily seen that $\{4,4\}$ 
strategies calls for quality control works to be carried after each operation and as a result, completely eliminating the failure costs. There are many important management implications illustrated in all the examples presented in this chapter. First, quality costs are very large when quality activities time window is sacrificed to reduce the total cycle time. Secondly, failure costs are very large and managers should completely avoid these costs since there is no trade off that exists with these costs. Another important issue is the fact that using simulation to measure and understand cost of quality has provide managers with opportunity to rank their process in terms of cost of quality and the cost consequences that resulted from adopting a specific set of strategies .

\section{Conclusions}

In this chapter, an analytical model reported in the literature for cost of quality computations was considered and modified to include an important component of cost of quality. The model is then used to develop a simulation model for a two-stage manufacturing system. Moreover, quality control strategies common in the manufacturing community were used in the simulation works to investigate their impact on cost of quality. The results indicate that some of these practiced strategies when combined with the detection periods will significantly increase cost of quality. Furthermore, the results indicate simulation works can be used to understand and measure cost of quality. An interesting venue for further research is to use simulation to investigate a real-industrial application to investigate the cost of quality; the authors are currently considering such idea.

\section{References}

Albright, T.L. and Roth, H. P (1992) .The measurement of quality cost: an alternative paradigm, Accounting Horizons, June, 15, 1992.

ASQC . (1971) Quality costs, what and how? Milwaukee: WI: ASQC Quality Press.

Bottorff, D. L.(1997). CoQ systems: the right stuff, Quality Progress, March, 33.

BS 6143 Part 2. (1990) Guide to determination and use of quality-related costs. London: BSI.

Burgess, T.F. (1996). Modeling quality cost dynamics, International Journal of Quality $\mathcal{E}$ Reliability Management, 13(3), .8-26.

Carr, L.P. (1992). Applying cost of quality to a service business, Sloan Management Reviews, 33(4), 72-78.

Chang, S.J., Hyun, P.Y. and Park, E. H. (1996). Quality costs in multi-stage manufacturing systems, Computers \& Industrial Engineering, 31(1-2), 115-118.

Chen, C.C. and Yang, C.C. (2002). Cost-effectiveness based performance evaluation for suppliers and operations, Quality Management Journal, 9(4), 59-73.

Chiadamrong, N. (2003). The development of an economic quality cost model, Total Quality Management and Business Excellence, 14(9), 999-1014.

Clark, H.J and Tannock, J.D.T. (1999), The development and implementation of a simulation tool for the assessment of quality economics within a cell-based manufacturing company, International Journal of Production Research, 37, 979-995.

Cooper, R. (1988). The rise of activity-based costing - Part I: What is an activity-based cost system?, Journal of Cost Management, 2(2),.45-54.

Cooper, R. and Kaplan, R. S. (1988). Measure costs right: Make the right decisions, Harvard Business Review, 66(5), .96-103.

Crosby, P. B. (1979). Quality is free, New York: McGraw-Hill. 
Crossfield , R. T. and Dale, B. G. (1990). Mapping quality assurance systems: a methodology, Quality and Reliability Engineering International, 6(3), 167-178.

Dale, B.G. and Plunkett, J. J. (1999). Quality Costing, 3rd ed., Gower Press, Aldershot.

Dawes, E.W. (1989). Quality costs-new concepts and methods, quality costs: ideas \& applications, in Campanella, J. (Ed.), Quality Costs: Ideas and Applications, Vol. 2(pp.440.), ASQC Quality Press, Milwaukee, WI.

Dawes, E.W. and Siff, W. (1993). Using quality costs for continuous improvement, ASQC Annual Quality Congress Transactions, 444-449.

Denton, D.K. and Kowalski, T.P. (1988). Measuring nonconforming costs reduced manufacturer's cost of quality in product by $\$ 200000$, Industrial Engineering, 20, 3643.

Feigenbaum, A. V. (1956). Total quality control, Harvard Business Review, 34(6), 93-101.

Feigenbaum, A. V. (1961). Total Quality Control, McGraw-Hill Inc., New York, USA.

Gardner, L.L, Grant, M.E. and Rolston, L.J. (1995). Using simulation to assess costs of quality, Proceedings of the Winter Simulation Conference.

Giakatis, G., Enkawa, T. \& Washitani, K. (2001). Hidden quality costs and the distinction between quality cost and quality loss, Total Quality Management, 12(2), 179-190.

Goulden, C. and Rawlins, L. (1995). A hybrid model for process quality costing, International Journal of Quality \& Reliability Management, 12(8), 32-47.

Gupta, M. and Campbell, V. S. (1995). The cost of quality, Productions and Inventory Management Journal, 36(3), 43-49.

Harry, M.J. and Schroeder, R. (2000). Six Sigma: The breakthrough management strategy revolutionizing the world's top corporations, New York: Doubleday, Random House.

Heagy, C.D. (1991). Determining optimal quality costs by considering costs of loss sales, Journal of Cost Management for the Manufacturing Industry, Fall, 67-71.

Hester, W.F. (1993). True quality cost with activity based costing, ASQC Annual Quality Congress Transactions, 446-453.

Jorgenson, D.M. and Enkerlin, M.E. (1992). Managing quality costs with the help of activity based costing, Journal of Electronics Manufacturing, 2, 153-160.

Juran, J .M. (1952). Quality Control Handbook (1st ed.). New York: McGraw-Hill.

Juran, J. M. (1989). Juran on Leadership for Quality. New York: Free Press.

Juran, J.M., Gryna, F.M. and Bingham, R. (1975). Quality Control Handbook, 3rd edition, New York, McGraw-Hill.

Kent, R. (2005). Manufacturing strategy for window fabricators 14 - the cost of quality, Tanagram Technology, available at: www.tanagram.co.uk.

Krishnan, S.K., Agus, A. and Husain, N. (2000). Cost of quality: The hidden costs, Total Quality Management, 11(4, 5 \& 6), 844-848.

Malchi, G. and McGurk, H. (2001). Increasing value through the measurement of the cost of quality (CoQ) - A practical approach, Pharmaceutical Engineering, 21(3), 92-95.

Marsh, J., (1989).Process modeling for quality improvement, Proceedings of the Second International Conference on Total Quality Management, IFS publication, Bedford, 111121.

Merino, D. N. (1988). Economics of quality: Choosing among prevention alternatives, International Journal of Quality \& Reliability Management, 5(7), 13-23.

Modarres, B. and Ansari, A. (1987). Two new dimensions in the cost of quality, International Journal of Quality \& Reliability Management, 4(4), 9-20. 
Morse, W. J. (1983). Consumer product quality control cost revisited, Measuring Quality Costs, Cost and Management, July/August, 16-20.

Moyer, D.R. and Gilmore, H.L. (1979) Product conformance in the steel foundry jobbing shop, Quality Progress, 12 (5),. 17-19.

Naylor, T.H., and Finger, J.M. (1967), Verification of computer models, Management Science, 14, pp92.

Omachonu, V.K., Suthummanon, S. And Einspruch, N. G. (2004). The Relationship Between Quality and Cost of Quality for a Manufacturing Company, International of Quality $\mathcal{E}$ Reliability Management, 21 (3), 277-290.

Plunkett, J.J. and Dale, B. G. (1988).Quality costs: A critique of some 'economic cost of quality' models, International Journal of Production Research, 26(11), 1713-1726.

Plunkett, J.J., Dale, B. G. (1987). A review of the literature on quality-related costs, International Journal of Quality \& Reliability Management, 4 (1), .40-52.

Prickett, T.W. and Rapley, C. W. (2001). Quality costing: A study of manufacturing organizations Part 2: Main survey, Total Quality Management, 12(2), 211-222.

Purgslove, A.B. and Dale, B. G. (1995). Developing a quality costing system: Key features and outcomes, Omega: International Journal of Management Science, 23 (5), 567-575.

Ross, D.T. (1977). Structured analysis (SA): A language for communicating ideas, IEEE Transactions on Software Engineering, 3(1), 16-34.

Sandoval-Chavez, D.A. and Beruvides, M. G. (1998). Using opportunity costs to determine the cost of quality: A case study in a continuous-process industry, Engineering Economist, 43(2), 107-124.

Schiffauerova, A. and Thomson, V. (2006). A review of research on cost of quality models and best practices, International Journal of Quality and Reliability Management, 23 (6), 647-669.

Sharma, J. K. (2007). Business Statistics, 2nd edition, Pearson Education India.

Son, Y.K and Lie, F.H. (1991), A method of measuring quality costs, International Journal of Production Research, Vol. 29, pp. 1785-1794.

Sorqvist, L. (1997). Effective methods for measuring the cost of poor quality, European Quality, 4 (3), 40-42.

Sumanth, D. J., and Arora, D. P. S.(1992). State of the art on linkage between quality, quality costs and productivity, International Journal of Materials and Product Technology, 7(2), 150-169.

Suminsky Jr., L. T. (1994). Measuring cost of quality, Quality Digest, 14 (3), 26-32.

Tannock, J.D.T. (1995). Choice of inspection strategy using quality simulation, International Journal of Quality E Reliability Management, Vol. 12, No. 6, pp. 75-84

Tannock, J.D.T. (1997). An economic comparison of inspection and control charting using simulation, International Journal of Quality E Reliability Management, Vol. 14, No. 7, pp. 687-700.

Tatikonda, L.U. and Tatikonda, R.J. (1996). Measuring and reporting the cost of quality, Production and Inventory Management Journal, 37(2), 1-7.

Tsai, W. H. (1998). Quality cost measurement under activity-based costing, International Journal of Quality and Reliability Management, 15(7), 719-752.

Weheba, G. S. and. Elshennawy, A. K. (2004). A revised model for the cost of quality, International Journal of Quality \& Reliability Management, 21(3), 291-308.

Yang, C.C. (2008). Improving the definition and quantification of quality costs, Total Quality Management, 19(3), March, 175 - 191. 


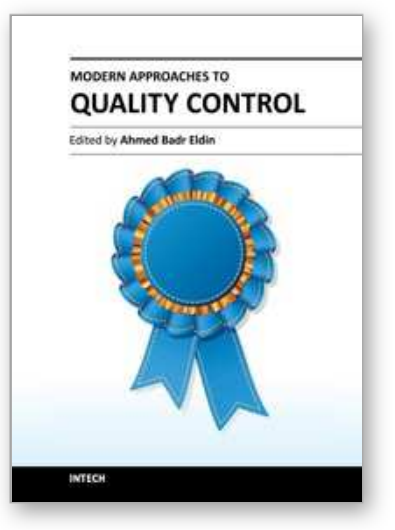

\author{
Modern Approaches To Quality Control \\ Edited by Dr. Ahmed Badr Eldin
}

ISBN 978-953-307-971-4

Hard cover, 538 pages

Publisher InTech

Published online 09, November, 2011

Published in print edition November, 2011

Rapid advance have been made in the last decade in the quality control procedures and techniques, most of the existing books try to cover specific techniques with all of their details. The aim of this book is to demonstrate quality control processes in a variety of areas, ranging from pharmaceutical and medical fields to construction engineering and data quality. A wide range of techniques and procedures have been covered.

\title{
How to reference
}

In order to correctly reference this scholarly work, feel free to copy and paste the following:

Mohamed K. Omar and Sharmeeni Murugan (2011). Evaluating Quality Control Decisions: A Simulation Approach, Modern Approaches To Quality Control, Dr. Ahmed Badr Eldin (Ed.), ISBN: 978-953-307-971-4, InTech, Available from: http://www.intechopen.com/books/modern-approaches-to-quality-control/evaluatingquality-control-decisions-a-simulation-approach

\section{INTECH}

open science | open minds

\author{
InTech Europe \\ University Campus STeP Ri \\ Slavka Krautzeka 83/A \\ 51000 Rijeka, Croatia \\ Phone: +385 (51) 770447 \\ Fax: +385 (51) 686166 \\ www.intechopen.com
}

\author{
InTech China \\ Unit 405, Office Block, Hotel Equatorial Shanghai \\ No.65, Yan An Road (West), Shanghai, 200040, China \\ 中国上海市延安西路65号上海国际贵都大饭店办公楼405单元 \\ Phone: +86-21-62489820 \\ Fax: +86-21-62489821
}


(C) 2011 The Author(s). Licensee IntechOpen. This is an open access article distributed under the terms of the Creative Commons Attribution 3.0 License, which permits unrestricted use, distribution, and reproduction in any medium, provided the original work is properly cited. 